\author{
Mariusz Furgał \\ Uniwersytet Jagielloński \\ (D) https://orcid.org/0000-0003-2983-2225 \\ https://doi.org/10.15633/9788374386753.10
}

\title{
Możliwość przenoszenia metod terapii rodzin na analizę konfliktów i sposobów im zapobie- gania i ich rozwiązywania w organizacjach
}

Człowiek w swoim życiu społecznym wchodzi w szereg współzależności i interakcji z innymi ludźmi na wielu płaszczyznach. Złożony system społeczny jest cechą naszego gatunku. Organizacja społeczna zapewnia ludziom przetrwanie, zaspokojenie podstawowych i złożonych potrzeb a także rozwój ${ }^{1}$. Nie sposób obecnie sobie wyobrazić indywidualnego funkcjonowania człowieka bez udziału innych ludzi lub choćby ich wytworów. Za sprawne, automatyczne funkcjonowanie grupowe człowieka odpowiedzialny jest jego system emocjonalny - filogenetycznie starszy od systemu racjonalno-intelektualnego, związany głównie z ośrodkami podkorowymi mózgu i często dominujący racjonalno-logiczne stany, których biologicznym substratem jest kora mózgu². System emocjonalny działa intuicyjnie, dostarcza szybkich, odruchowych rozwiązań, często skutecznych, jednak jest podatny na występowanie błędów poznawczych i nie podlega bezpośredniej, świadomej, rozumowej kontroli ${ }^{3}$ System emocjonalny, jakkolwiek stwarza nam możliwości współzależnego istnienia, w wielu sytuacjach może generować niepożądane skutki. Negatywna ocena charakteru tych skutków pochodzi wówczas ze strony naszego systemu racjonalno-logicznego.

Psychoterapia od początku XX wieku zajmowała się rozwojem praktycznej metodyki radzenia sobie ze stanami emocjonalnymi, początkowo skupiając się na świecie wewnętrznym człowieka, z jego wewnętrznymi

\footnotetext{
1 Por. Y.N. Harari, Sapiens. Od zwierząt do bogów, Wydawnictwo Literackie, Warszawa 2018, s. 23.

2 Por. P. Luyten, P. Fonagy, The Neurobiology of Mentalizing, „Personality Disorders: Theory, Research, and Treatment" (2015) no. 6(4), s. 366-379.

3 Por. D. Kahneman, Pułapki myślenia, Media Rodzina, Poznań 2012, passim.
} 
konfliktami, później wdrażając praktyki terapeutyczne wobec grup społecznych w postaci psychoterapii grupowej i rodzinnej. Terapia rodzin dynamicznie rozwija się od połowy $\mathrm{XX}$ wieku${ }^{4}$, badając naturę relacji międzyludzkich w podstawowym dla ludzi środowisku - rodzinie.

Nie sposób pominąć znaczenia funkcjonowania ludzi w swoich rodzinach dla późniejszego funkcjonowania w relacjach. To tam powstają prototypy emocjonalnego przeżywania relacji i zachowań interakcyjnych. W terapii rodzin od lat gromadzona jest wiedza na temat funkcjonowania ludzi w bliskich relacjach i rozwijane są narzędzia służące regulacji zaburzonych i nieefektywnych współzależności. Stąd warto rozważać użycie tej wiedzy do analizy konfliktów w innych, połączonych więziami emocjonalnymi grupach ludzkich - w szczególności różnego rodzaju organizacjach. Techniki terapeutyczne mogą być użyteczne w procesie rozwiązywania konfliktów, w tym również $\mathrm{w}$ mediacjach. Wybrane narzędzia terapii rodzin mogą być przydatne w rozwiązywaniu konfliktów organizacyjnych. Niedostępność indywidualnych historii rozwoju członków nie jest sama w sobie przeszkodą, gdyż różne przejawy funkcjonowania interpersonalnego, jakie można obserwować w rodzinach, są widoczne w interakcjach społecznych w organizacji ${ }^{5}$.

W czasie dorastania i socjalizacji w rodzinach wykształcają się wzorce emocjonalne funkcjonowania $\mathrm{w}$ grupie. Te wzorce uaktywniają się w innych kontaktach społecznych, powodując, że wiele zjawisk występujących w organizacjach możemy odnosić do systemowych właściwości środowiska rodzinnego. Literatura poświęcona mediacjom zawiera odniesienia do twórców terapii rodzin, takich jak Paul Watzlawik czy John Weakland ${ }^{6}$.

\section{Konflikty w rodzinach i organizacjach}

Czesław Sikorski wyróżniał konflikty:

- osobowościowe (związane z cechami indywidualnymi członków organizacji);

4 Por. L. Hoffman, Family therapy: An intimate history, W. W. Norton \& Company 2002, passim.

5 Por. J. Jabłońska-Dzierża, W. Łodej-Sobańska, J. Marczewska, J. Pawlik, Podstawowe procesy izjawiska $w$ terapeutycznej grupie analitycznej, w: Psychoterapia analityczna. Procesy i zjawiska grupowe, red. J. Pawlik, Eneteia, Warszawa 2008, s. 57-107.

6 Por. P. Senge, Iść naprzód; Strategiczne myślenie o budowaniu organizacji uczacych się, w: P. M. Senge, A. Kleiner, C. Roberts, R. B. Ross, \& B.J. Smith, Piata dysyplina; Materaiaty dla praktyka. Jak budować organizację uczącq się, Wolters Kluwer, Warszawa 2013, s. 31-65. 
- kulturowe (związane z poglądami, postawami, normami i wartościami członków);

- strukturalne (związane z hierarchią władzy lub podziałem pracy);

- funkcjonalne (związane z przebiegiem procesów i interakcji jednostek i grup) ${ }^{7}$.

Przyglądając się powyżej przedstawionej klasyfikacji, można zauważyć, że wszystkie te rodzaje konfliktów mają swój pierwowzór w rodzinach. Należy przy tym wskazać, że konflikt w rodzinie jest naturalnym sposobem adaptowania się rodziny do zadań bieżących i rozwojowych. Konflikty mają naturalną funkcję regulacyjną wszędzie tam, gdzie musi dojść do ustabilizowania modus vivendi dwóch różnych osobowości (a nawet płci), integracji dwóch różnych kultur wyniesionych $\mathrm{z}$ różnych rodzin pochodzenia $-\mathrm{z}$ ich zwyczajami, mitami i przekazami. Musi dojść do ustalenia systemu władzy, odpowiedzialności i podziału zadań8.

W terapii rodzin w wielu przypadkach musimy się skupić raczej na poprawie zdolności rodziny do radzenia sobie z konfliktami, zmniejszeniu poziomu wrogości, tworzeniu praktyk osiągania kompromisów, a nie tylko na likwidacji konfliktów. Posłużmy się przykładem konfliktu wokół podejścia wychowawczego wobec dziecka, gdzie jedna ze stron stoi na stanowisku dawania dziecku większej swobody, a druga jest rzecznikiem kontroli, obowiązków i rygorów. Zarówno jedna, jak i druga strategia wychowawcza służy prawidłowemu rozwojowi dziecka pod warunkiem istnienia pewnej równowagi - jeśli dziecko ma zbyt dużo swobody i spontaniczności, konieczne jest stosowanie dyscypliny i rygoru, jeśli ma zbyt dużo obowiązków, konieczne jest stworzenie warunków dla zabawy i swobodnych zachowań. Konflikt między tymi biegunami jest naturalnym konfliktem wewnętrznym każdego rodzica. W parze może on się uzewnętrznić - wówczas każdy z rodziców unika wewnętrznego konfliktu, wchodząc w konflikt z drugim rodzicem, obejmującym przeciwne stanowisko. Mamy wówczas do czynienia ze znanym terapii par od końca lat 6o. XX wieku zjawiskiem polaryzacji9.

Naturalne, regulacyjne konflikty mogą się wiązać z aktywowaniem różnych innych uczuć i sprzyjać polaryzowaniu się w innych obszarach.

7 Por. C. Sikorski, Jezzyk konfliktu. Kultura komunikacji społecznej w organizacji, Wydawnictwo C.H. Beck, Warszawa 2005.

8 Por. I. Namysłowska, Terapia rodzin, Wydawnictwo Naukowe PWN, Warszawa 1997, s. 13-17.

9 Por. H.V. Dicks, Marital Tensions: Clinical Studies Towards a Psychological Theory of Interaction, Routledge, New York 1993, s. 113. 
Na przykład w powyższej sytuacji może wystąpić konflikt wartości wyniesionych $\mathrm{z}$ rodzin pochodzenia - wzbudzenie postaw lojalności wobec pozostających $w$ konflikcie wartości wyniesionych $\mathrm{z}$ tych rodzin. Ten rodzic, w którego rodzinie przywiązywano dużą wagę do dyscypliny, może wejść $\mathrm{w}$ destrukcyjną walkę na tym polu z rodzicem, którego przekaz rodzinny stawia wyżej swobodę rozwoju.

$\mathrm{W}$ organizacjach społecznych innych niż rodziny polaryzacja stanowisk jest często spotykanym zjawiskiem. Strony sporu w tym właśnie mechanizmie rezygnują z próby rozumienia i uznania stanowiska drugiej strony, by uwydatnić i obronić swoje stanowisko. Rola mediatora i terapeuty w takiej sytuacji jest podobna. Musi on utrzymać ambiwalentną wizję problemu i próbować zachęcać strony do identyfikacji z przeciwnym stanowiskiem.

Ważne dla zrozumienia dynamiki konfliktu jest rozpoznanie istnienia ambiwalentnych uczuć. Czasem zaangażowane strony nie są świadome, że oprócz negatywnych uczuć żywią wobec siebie także pozytywne, często w sytuacji rozwiniętego zewnętrznego konfliktu wyparte. Jedną z osi konfliktu w parach trafiających na terapię jest występowanie sprzecznych uczuć w stosunku do partnera, przy czym uczucia, które wiążą i zbliżają partnerów, pozostają nieświadome. Tak jest, gdy ktoś kogoś pragnie, ale nie może zaspokoić swojego pragnienia bliskości, w związku z czym uruchamia się złość. Łatwiej w takiej sytuacji jest złościć się i atakować, niż pragnąć i pożądać bez możliwości (subiektywnej lub obiektywnej) zaspokojenia ${ }^{10}$. Znajomość tego zjawiska pozwala zrozumieć, dlaczego w długich, intensywnych związkach pozostają partnerzy, w których relacjach dominuje nienawiść. Ta dynamika może wyjaśniać nasilone konflikty między osobami, których współpraca dotąd przebiegała w harmonii i przyjaźni. Zawód rozbudzonych oczekiwań jest często przyczyną napięć, eskalując tak, że znika perspektywa możliwości powrotu do dawnej relacji współpracy i wzajemnego zaspokajania ważnych potrzeb. W mediacjach to zjawisko należy brać pod uwagę, gdy pomiędzy stronami konfliktu występowały dobre, a nawet zażyłe relacje w przeszłości. Występuje tu zjawisko swoistej „zdrady” uczuciowej i zawodu nadziei. W relacji w miejsce wzajemnej fascynacji, sympatii, a nawet wspólnej ekscytacji pojawia się złość. Łatwiej w takiej sytuacji się złościć, niż pozostawać z niezaspokojonymi potrzebami. W relacjach 
wewnątrz organizacji taka zmiana emocjonalna może być poprzedzona niedotrzymywaniem umów - zwykle nieformalnych, budzących nadzieję na rozwój i współpracę - czy zmianą rangi współpracy. Sytuacja taka może być celowym działaniem, ale czasem osoba raniąca zaangażowaną drugą stronę może nie być tego świadoma. Z punktu widzenia mediacji wyjaśnianie nieświadomie zawiedzionych nadziei może rokować na stosunkowo sprawne złagodzenie albo rozwiązanie konfliktu. Trudność takich mediacji będzie polegała jednak na zapewnieniu na tyle bezpiecznej emocjonalnie atmosfery rozmów, żeby strony mogły takie zawody ujawniać - bez skutku w postaci powodowania poczucia winy drugiej strony. Bardzo trudne w sytuacji konfliktu może być takie ujawnienie zawodu, które nie będzie zarzutem czy oskarżeniem. Można to czasem osiągnąć przez pozytywne przeformułowanie zarzutu np. „Rozumiem, że pana asystent przyjął pana nadzieję za obietnicę, a to, że ona się nie spełniła, za wycofanie pana zaangażowania, zatem - co zrozumiałe - jest zawiedziony, co nie znaczy, że pan miał na to jakiś wpływ".

\section{Kontekst zgłaszania się do terapii i ujawniania problematycznego konfliktu}

W terapii rodzin lub par osoby zwracają się o pomoc zwykle dopiero wtedy, gdy lokalne możliwości rodziny zostaną uznane za niewystarczające. Udanie się po pomoc do obcej osoby w przypadku dobrze wyodrębnionych systemów, jakimi są rodziny, jest raczej ostatecznym wyjściem, na które strony decydują się po wyczerpaniu lokalnych rodzinnych strategii, czasem po wyczerpaniu możliwości włączania innych bliskich osób (członków dalszej rodziny, przyjaciół) jako stabilizujących konflikt. Zaproszenie osoby bliskiej - bezpośrednio zaangażowanej w sprawy rodziny lub jej członków - do pomocy w rozwiązywaniu konfliktu jest z założenia gorszym wyjściem. Taka osoba może nie mieć odpowiedniej perspektywy, łatwiej jej o stronniczość, sama może być nadmiernie obciążona faktem włączenia w konflikt (tak na przykład dzieje się z dziećmi, które podejmują odpowiedzialność za konflikt rodziców, czasem będąc przez nich wciąganymi w koalicje, co skutkuje później objawami u dzieci). Włączanie obcych z kolei związane bywa z uczuciem nieadekwatności społecznej czy wstydu. Włączanie obcej osoby może także być rozpoznawane jako możliwość 
pozyskania przez jedną ze stron stronnika, a przez to może prowadzić do eskalacji takiego konfliktu - tym razem dodatkowo o pozyskanie owego stronnika. W konfliktach w obrębie organizacji warto zwracać uwagę, że - podobnie jak w rodzinach - włączenie obcej osoby do zażyłego konfliktu, by go pomóc rozwiązać, może być obarczone uczuciem wstydu, łamania tradycji czy naruszenia lojalności wewnątrzgrupowej. W takiej sytuacji ważne jest, by dochodziło wcześniej - na podstawie sygnałów - do wprowadzenia osoby trzeciej, zaangażowanej do rozwiązania konfliktu. O ile w rodzinie takie posunięcie byłoby naruszeniem zasad etycznych (może poza obszarem konfliktów, którym towarzyszy jawna przemoc albo naruszenie dobra dziecka), to w innych organizacjach społecznych takie podejście byłoby jak najbardziej uprawnione i pożądane ze względu na możliwość rozpoczęcia procesu opracowania i rozwiązania konfliktu jeszcze przed wystąpieniem z jego powodu zasadniczych szkód. Stąd ważne, żeby organizacje dysponowały mechanizmami, które umożliwią identyfikację i interwencję w konfliktach na wczesnym ich etapie. Zaistnienie takiej możliwości oczywiście nie zwalnia mediatora $\mathrm{z}$ wrażliwości w postępowaniu i świadomości, że jednym ze skutków „przyłapania” stron na konflikcie może być jego eskalacja albo ukrycie.

Jednym z objawów toczącego się konfliktu w rodzinie może być dysfunkcja dziecka. Często taki konflikt jest maskowany przez objawy dziecka, które wówczas zostaje tak zwanym identyfikowanym pacjentem ${ }^{11}$. Mogą to być objawy psychosomatyczne, psychopatologiczne albo innego rodzaju dysfunkcja (używanie substancji, trudny bunt adolescencyjny, czy wagarowanie). Często objawy dziecka są wtórne do dysfunkcji pary rodzicielskiej, która dystansuje się od swojego problemu, skupiając uwagę na problemach dziecka. W procesie diagnozy czy konsultacji taka sytuacja jest identyfikowana i nazywana przez terapeutę, wskutek czego często później dziecko jest wyłączane z terapii. Wśród terapeutów dla opisu takiej sytuacji funkcjonuje powiedzenie, że dziecko przyprowadziło rodziców na terapię. Na podobne zjawisko - kumulację napięcia emocjonalnego rodziny w dysfunkcji jednego z jej członków - zwrócił później uwagę także Murray Bowen ${ }^{12}$. Przyjmując, że konflikty w rodzinie mogą dotykać jej niektórych członków,

11 Por. G. Bateson, Steps to an Ecology of Mind: Collected Essays in Anthropology, Psychiatry, Evolution, and Epistemology. Northvale, Jason Aronson Inc., London 1987, s. 174.

12

Por. M. Bowen, Intrafamily dynamics in emotional illness, w: Family Therapy in Clinical Practice, ed. M. Bowen, Jason Aronson Inc., New York 1978, s. 103-117. 
powodując ich dysfunkcję, należałoby się zastanowić, jak ma się to do innych organizacji społecznych. Taka dynamika napięć wskazywałaby na to, że w wypadku konfliktu w organizacji jednym z najwcześniejszych sygnałów konfliktów może być dysfunkcja niektórych członków takiej grupy, nawet jeśli jeszcze konflikt nie ujawnia się wprost. Dysfunkcja będzie dotyczyła najczęściej jednostek, które nie potrafią się sprawnie bronić z powodów systemowych (roli i pozycji w organizacji) czy osobowościowych. Może to mieć formę załamania się kariery dobrze dotąd funkcjonującego pracownika czy porażki egzaminacyjnej studenta, który poddany został presji emocjonalnej, niekoniecznie zresztą jako główna strona konfliktu. Negatywne uczucia w konfliktach mogą być przemieszczane nie tylko na oponenta, ale także na osoby z nim związane, ale bardziej wrażliwe na atak. Bazując na takim rozumieniu dynamiki emocjonalnej w grupach, można szukać możliwości wczesnej identyfikacji konfliktu poprzez identyfikację „kozła ofiarnego" procesu grupowego ${ }^{13}$.

Konflikt zidentyfikowany przez zewnętrzną instancję - terapia z nakazu lub zalecenia sądu/ośrodka adopcyjnego etc. - jest jednym z najtrudniejszych do rozwiązania $\mathrm{w}$ drodze psychoterapii, ponieważ strony często nie tylko nie mają motywacji do rozwiązania, ale także mogą traktować gabinet terapeutyczny jako miejsce zdobywania dowodów czy argumentów w sporze dla kierującej instytucji. Niektóre z tych terapii z powodzeniem się rozwijają, jeśli uda się odsłonić własną motywację pacjentów do zmiany, ale w większości przypadków takie terapie kończą się na wczesnym etapie - jeszcze przed ustaleniem celów terapii, niezależnych od zamysłu kierującej instytucji ${ }^{14}$. W sytuacji mediacji w konfliktach ta trudność nie występuje w takim stopniu jak w psychoterapii. Tak jak opisano powyżej, problemy własnej motywacji rodziny do podjęcia psychoterapii nie dotyczą w podobnym stopniu organizacji. W sytuacjach konfliktu w organizacjach taka „zewnętrzna” motywacja może być pozytywnym elementem kultury organizacji, choć oczywiście wspólna motywacja uczestników konfliktu do szukania pomocy jeszcze przed zewnętrznym zidentyfikowaniem konfliktu może być nieoceniona dla procesu naprawczego.

Por. J. Jabłońska-Dzierża, W. Łodej-Sobańska, J. Marczewska, J. Pawlik, Podstawowe procesy izjawiska w terapeutycznej..., dz. cyt., s. 57-107. 


\section{Podejścia w terapii rodzin i par przydatne w praktyce rozwiązywania konfliktów w organizacjach}

\section{Podejście strukturalne}

W terapii rodzin podejście strukturalne cechuje się skupieniem na kwestiach: granic pomiędzy podsystemami, hierarchii międzypokoleniowej, tworzących się podsystemów, przymierzy i koalicji1 ${ }^{15}$. Dysfunkcja rodziny może się wiązać z zaburzeniem struktury, czyli funkcjonalnych, przewidywalnych wzorców interakcji. Podstawą dobrej struktury - według twórców tego podejścia - jest hierarchiczny układ rodziny, gdzie więcej praw, władzy i obowiązków wiąże się z pozycją rodzica czy starszego dziecka. Granice międzypokoleniowe są wyraźne, ale nie sztywne, blokujące kontakt. Przymierza i koalicje są wyraźne w podsystemach dzieci i rodziców, ale nie międzypokoleniowo ${ }^{16}$. Ten zestaw metafor organizacyjno-przestrzennych przydatny jest przy ocenie funkcjonowania organizacji, w których struktura ma duże znaczenie. Takie zjawiska jak koalicje (nawiązywanie relacji między dwiema osobami w opozycji do trzeciej), zaburzenia granic - zbyt sztywne, czyli brak dostępu i dialogu między osobami z dwóch poziomów hierarchii albo zbyt przepuszczalne, czyli wchodzenie w pozaformalne (czy pozakonwencjonalne) relacje i komitywy osób z różnych poziomów hierarchii. Przed zaburzeniami wynikającymi z wad granic chronić może z jednej strony kultura organizacji, kładąca nacisk na etykę pracy, zakładająca etyczną postawę $\mathrm{w}$ relacjach nie tylko z klientami, ale także koleżeńskich. Z drugiej strony znaczenie ma rozwój wrażliwości i przyjmowanie „opiekuńczej” postawy wobec osób znajdujących się niżej w hierarchii. W organizacjach można się spotkać $\mathrm{z}$ koalicjami przełożonego z podwładnym przeciwko innemu podwładnemu, może to mieć postać promowania jednej osoby kosztem drugiej. Nieharmonijny rozwój zespołów powinien zwracać uwagę mediatorów, gdyż może być właśnie przejawem transhierarchicznych koalicji, co może poprzedzać rozwój konfliktów. Także zbyt szczelne granice między przełożonym a podwładnym albo przeciwnie - brak granic - mogą skutkować

15 Por. S. Minuchin, Families and Family Therapy, Harvard University Press Cambridge, Massachusetts 1974, s. 51-66.

16 Por. H. Goldenberg, I. Goldenberg, Terapia rodzin, Wydawnictwo Uniwersytetu Jagiellońskiego, Kraków 2006, s. 231. 
dysfunkcjami systemu. W przypadku międzyhierarchicznych koalicji możemy mieć do czynienia ze zbyt przepuszczalnymi granicami między przełożonym a jednym podwładnym, a zbyt sztywnymi w relacjach $z$ drugim. Granice mogą tu określać takie zwyczaje jak: formalizowanie kontaktu, regulowanie dostępności dla podwładnych, możliwość podejmowania prywatnych czy osobistych rozmów między przełożonym a podwładnym, plotkowanie, wspólne spędzanie czasu poza pracą etc.

\section{Podejście komunikacyjne}

W podejściu komunikacyjnym $\mathrm{w}$ terapii rodzin kładzie się nacisk na śledzenie sekwencji interakcji i hierarchii interakcji rodzinnych, na rozumienie, jak dochodzi do dysfunkcjonalnych wzorców odnoszenia się do siebie. Jest to podejście o tyle przydatne w mediacjach, że w niewielkim stopniu - albo wcale - nie odnosi się do przeszłości, nastawione jest na analizę zachowań komunikacyjnych w teraźniejszości. Jego celem jest pomoc w rozwiązaniu aktualnego problemu, w mniejszym stopniu stymulacja rozwoju jednostek czy praca nad ukrytymi konfliktami ${ }^{17}$. W myśl podejścia komunikacyjnego każde zachowanie jest komunikacją. Komunikacja zachodzi na różnych poziomach: werbalnym, behawioralnym, a także na innych niewerbalnych kanałach komunikacji. Komunikacja ma aspekt treściowy i relacyjny (polecenia). Treść komunikatu może być różnie odebrana w zależności od relacji stron komunikujących się i od kontekstu zewnętrznego. Na przykład w domu, w którym mąż zwykle dostaje jedzenie po powrocie z pracy od żony, gospodyni domowej, komunikat ,jestem głodny” oznacza polecenie wydania posiłku. Gdyby skupić się tylko na treściowym znaczeniu tego komunikatu, adekwatna odpowiedź - „To współczuję, musisz się źle czuć” - będzie zupełnie nieadekwatna w tej relacji i może prowadzić do rozwoju konfliktu. Komunikacja ma więc aspekt relacyjny, określa stosunek dominacji/submisji, jeśli jest to relacja komplementarna, chociaż relacja może mieć także charakter symetryczny, gdzie nie da się ustalić, kto ma czyje polecenia wykonywać ${ }^{18}$. Oczywiście stosunek dominacji/submisji nie musi oznaczać trwałej relacji, może ona być zależna od kontekstu. Ta sama żona może w innej sytuacji powiedzieć: „Trzeba wkręcić żarówkę” - komunikując nie tyle stwierdzenie

17 Por. H. Goldenberg, I. Goldenberg, Terapia rodzin..., dz. cyt., s. 248.

18 Por. H. Goldenberg, I. Goldenberg, Terapia rodzin..., dz. cyt., s. 253. 
istniejącej potrzeby, tylko określając polecenie dla męża, który w tej sytuacji jest $\mathrm{w}$ roli submisyjnej. Tak więc komunikaty mają warstwę syntaktyczną, semantyczną i pragmatyczną.

Aspekty pozawerbalne i kontekstualne są niezwykle istotne, gdyż ich nieokreślenie, nieznajomość czy pominięcie $\mathrm{w}$ analizie i refleksji mogą prowadzić do konfliktów, ale także uniemożliwiać efektywne radzenie sobie z takimi konfliktami. Stąd w próbach mediacji w konfliktach wewnątrz organizacji tak ważna będzie dla mediatora znajomość kontekstu komunikacji. Szczególnie ważne będzie rozpoznanie ról, w których występują strony konfliktu - kto zajmuje dominującą, a kto submisyjną pozycję - nie w strukturach formalnych, ale komunikacyjnych. Z takiej przesłanki wynika postulat wcześniejszego rozpoznania terenu mediacji przed jej rozpoczęciem, ale także w trakcie. Zrozumienie lokalnej kultury komunikacyjnej może być zasadnicze dla skuteczności rozpoznania mediatora.

Podejście komunikacyjne zwraca także uwagę na to, że komunikaty w relacjach między ludźmi mogą mieć charakter potwierdzający, zaprzeczający i ignorujący. Ten ostatni jest szczególnie dotkliwą formą komunikacji, ponieważ eliminuje stronę z dialogu, nie dopuszczając jej nawet jako ważnego uczestnika konfliktu. Taka postawa towarzyszyć może różnym formom nadużywania władzy, które są trudno identyfikowalne jako problematyczne zarówno w rodzinie, jak i innych grupach społecznych. Virginia Satir, jedna z czołowych przedstawicielek podejścia komunikacyjnego w terapii rodzin, wyróżniała kilka form dysfunkcjonalnej komunikacji związanych z dysfunkcją rodziny ${ }^{19}$. Była to komunikacja: niebezpośrednia, niejasna, niepełna, niezrozumiała, niedokładna, zniekształcona lub niewłaściwa. Uważała, że komunikacja w rodzinie odzwierciedla poczucie własnej wartości jej członków. Wyróżniała cztery style dysfunkcjonalnej komunikacji:

- łagodzący (usługiwanie) - osoba taka ujawnia słabość, niepewność, usuwa się w cień, zgadza się, przeprasza, próbuje zadowolić innych. Stoi za tym przekonanie: „Jestem niczym, bez ciebie nic nie znaczę”;

- obwiniający (władza) - osoba taka jest „nieomylna”, czepia się, oskarża, dominuje co jest pochodną przekonania: "Jestem samotnym nieudacznikiem";

- superrozsądny (intelekt) - taki ktoś zajmuje sztywne stanowisko, utrzymuje dystans, jest spokojny, na luzie, utrzymuje kontrolę

19 Por. H. Goldenberg, I. Goldenberg, Terapia rodzin..., dz. cyt., s. 175-181. 
intelektualną, unika zaangażowania emocjonalnego wynika to $\mathrm{z}$ wewnętrznego przekonania: „Czuję się słaby”;

- niedopasowany (spontaniczność) - ta osoba odwraca uwagę, wydaje się niezdolna do odniesienia się do czegokolwiek, boi się obrazić czy zranić kogoś przez zajęcie stanowiska w jakiejś sprawie, a jest to pochodną wewnętrznego przekonania: „Nikogo nie obchodzę, nie ma dla mnie miejsca".

Innym obszarem analizy w komunikacyjnym podejściu w terapii rodzin jest komunikacja paradoksalna, zwana także podwójnym wiązaniem ${ }^{20}$. Taka sytuacja komunikacyjna ma miejsce, gdy jedna osoba odbiera od drugiej sprzeczne komunikaty, zazwyczaj nadawane na różnych kanałach. Jest to stosunkowo częste zakłócenie komunikacji - gdy postawa niewerbalna przeczy werbalnie wyrażanemu komunikatowi, jednak czasem jest szczególnie problematyczna, jeśli komunikat pochodzi od osoby dominującej. Osoba w roli submisyjnej dostaje nakaz, któremu należy się podporządkować, ale jednocześnie nie można się podporządkować. Odbiorca rozpoznaje sprzeczne oczekiwania, wyrażone w jednym komunikacie. Nie jest w stanie ominąć niespójności ani jej skomentować. Tak na przykład dzieje się, gdy młody człowiek - emocjonalnie zależny od swojej matki - dostaje komunikat, że może ze spotkania wrócić dowolnie późno, ale dodatkowo słyszy, że matka będzie na niego czekała. Sytuacja takiego podwójnego komunikatu powoduje silny konflikt wewnętrzny i wyraźne dysfunkcje w zachowania czy wykonywaniu zadań. Duża ilość podwójnych komunikatów może być sama w sobie źródłem konfliktu. Wśród technik terapeutycznych podejścia komunikacyjnego można wymienić stymulowanie rodziny do swobodnego wyrażania uczuć - poprzez stosowanie pozytywnych przeformułowań, odkrywanie i demaskowanie ukrytych reguł komunikacji i zachowań, klaryfikowanie niejasnych informacji, mówienie we własnym imieniu, mówienie wprost do siebie, a nie o kimś. Terapia jest miejscem uczenia się wzorców komunikacji. Terapeuta funkcjonuje jako osoba źródłowa - model komunikacji (przykłady dobrej komunikacji, jak do niej dojść, przejrzystość). W terapii ma miejsce analiza technik używanych przez każdego członka rodziny do radzenia sobie z istnieniem odmienności, prowadzi się funkcjonalną analizę ról (np. odkrywanie

20 Por. G. Bateson, Steps to an Ecology of Mind: Collected Essays in Anthropology, Psychiatry, Evolution, and Epistemology. Northvale, Jason Aronson Inc., London 1987, s. 199-203. 
dominacji i submisji w komunikacji) ${ }^{21}$. Techniki te wprost mogą być używane w procesie mediacji. W pracy w obszarze komunikacji praca mediatora niewiele będzie się różniła od pracy psychoterapeuty. $W$ obu przypadkach można pracować, nie dokonując głębokich introspekcji czy analizy historii rozwoju osób uczestniczących w konflikcie. Może to być wystarczające do rozwiązania konfliktu, a nawet więcej, może być formą edukacyjno-szkoleniową, zapobiegającą w przyszłości rozwojowi konfliktów wynikających z zakłóconej komunikacji.

\section{Podejście mediolańskie}

Rozwinięte w latach 8o. XX wieku w Mediolanie podejście w terapii rodzin zmieniało obowiązujące do tej pory w terapii rodzin paradygmaty. Zakładało pracę $\mathrm{z}$ rodziną $\mathrm{w}$ taki sposób, że terapeuta stawał się jednym $\mathrm{z}$ elementów systemu rodzinnego, katalizującym procesy zmiany w oparciu o zasoby systemu rodzinnego. Głównymi cechami tego podejścia są: cyrkularność, hipotezowanie/odrzucanie hipotez oraz neutralnośćc 22 .

\section{CYRKULARNOŚĆ}

Systemowa terapia rodzin postuluje ograniczenie myślenia przyczynowo-skutkowego jako modelu rozumienia interakcji. W zamian za to proponuje podejście cyrkularne, w którym zakładamy, że przyczyna powoduje skutek, ale zwrotnie, skutek może modyfikować przyczynę. Zazwyczaj dochodzenie do tego, co było na początku, jest niemożliwe, a nawet niezasadne i nieefektywne, jedynie nasila proces obwiniania i tworzenia zarzutów ${ }^{23}$. Przykładowo, jeśli mąż unika kontaktów z żoną, bo ta robi mu wyrzuty, a żona nasila wyrzuty, bo mąż unika z nią kontaktu. Szukanie pierwotnej przyczyny jedynie nasila te zachowania w mechanizmie dodatniego sprzężenia zwrotnego. W terapii systemowej terapeuci koncentrują się raczej na pragnieniach, motywacjach i szukaniu alternatywnych sposobów relacji, które doprowadziłyby

21 Por. L. Heatherington., M. L. Friedlander, Complementarity and symmetry in family therapy communication, „Journal of Counseling Psychology”(1990) no. 37(3), s. 261-268. Por. H. Goldenberg, I. Goldenberg, Terapia rodzin..., dz. cyt., s. 283; M. Selvini Palzolli, L. Boscolo, G. Cecchin, G. Prata, Hypothesizing - Circularity - Neutrality: Three Guidelines for the Conductor of the Session, „Family Process” (1980) no. 19, s. 3-12. 
do osłabienia, a później wygaszenia tego sprzężenia, a także do rozumienia mechanizmu impasu.

\section{HIPOTEZOWANIE}

Innym przydatnym $w$ terapii rodzin i par narzędziem, wprowadzonym przez zespół z Mediolanu, jest proces stawiania i odrzucania hipotez. Stanowi on zmianę w stosunku do wcześniejszej praktyki szukania wyjaśnień i interpretacji. Zakłada on zdystansowany stosunek terapeuty do własnego rozumienia problemu, a w szczególności do przekazywania rodzinie hipotez i interpretacji na temat zjawisk dostrzeżonych i zinterpretowanych przez terapeutę. W podejściu tym stawia się na ciągłe generowanie hipotez i przyjmowanie ich dopiero po stwierdzeniu, że hipoteza jest akceptowana przez rodzinę. Zakłada, że nawet najlepsze i najbardziej wnikliwe hipotezy są nieużyteczne, jeśli z jakichś powodów rodzina nie jest ich w stanie przyjąć i zasymilować. Wymusza to na terapeucie generowanie wielu alternatywnych hipotez, testowanie ich w rozmowie $\mathrm{z}$ rodziną, odrzucanie tych, które w danym momencie nie są przyjęte. Terapeuta przyjmuje postawę irrewerencji - lekceważenia własnych hipotez. Kolejne hipotezy są tworzone na bazie tych już przyjętych. Zakłada się tutaj, że lepsza jest nie ta hipoteza, która jest bardziej prawdziwa, ale ta, która jest bardziej użyteczna. Taka metoda pracy ze stronami pozostającymi w konflikcie działa na co najmniej dwóch poziomach. Na poziomie poznawczym pozwala na szukanie wyjaśnień sporu - innych niż strony początkowo zakładały. Pozwala to na zmianę perspektywy i dostrzeżenie alternatywnych wyjaśnień trudnej sytuacji ${ }^{24}$. W razie zbytniego przywiązania osoby pomagającej w rozwiązywaniu konfliktu do własnych pomysłów szybko może dojść do ustanowienia trzeciej strony sporu, która do dwóch narzucanych wersji dodaje jeszcze jedną. Jeśli mediator przyjmie pozycję elastyczną i będzie poszukiwał alternatyw do momentu aż będą one do przyjęcia dla obu stron, to istnieje szansa na wyjście z narracji walki o posiadanie racji. Postawa dystansu do własnych przekonań daje nadzieję na wzbudzenie podobnego podejścia u obu stron konfliktu i na rozpoczęcie dialogu. Na drugim poziomie - emocjonalnym - wskutek wzbudzenia aktywności poznawczej i refleksji dochodzi do redukcji napięcia emocjonalnego i uruchomienia procesów myślowych. Takie zjawisko wykorzystywane jest przez większość podejść terapeutycznych, w różnych teoriach i podejściach

24 Por. H. Goldenberg, I. Goldenberg, Terapia rodzin..., dz. cyt., s. 283. 
analizujących emocjonalne sytuacje ze wspólnym dla wszystkich efektem lepszej kontroli i rozumienia emocji ${ }^{25}$.

\section{NEUTRALNOŚĆ}

Neutralność terapeuty, choć zazwyczaj intuicyjnie ważna w terapii rodzin, w podejściu mediolańskim nabrała szczególnego znaczenia jako narzędzie pracy. Przy głębszej analizie tej postawy terapeuty okazało się, że postawa neutralna w wielu przypadkach, a może w większości z nich, jest postulatem idealnym. Każdy z nas żyje w pewnych systemach wartości i osądów, co ma znaczenie dla tego, po czyjej stronie w sporach jesteśmy skłonni się opowiadać. Neutralność w terapii rodzin zaczęła od tego czasu oznaczać bardziej świadome utrzymywanie pewnej postawy. Postawa ta zakłada obserwowanie własnego zaangażowania w strony konfliktu, świadomość stronniczości i ciągłe balansowanie między bliskością a odległością od obu stron w taki sposób, że gdy terapeuta zauważa, że się od którejś strony oddala, to podejmuje świadomy wysiłek, by z tą stroną bardziej się identyfikować i bardziej ją rozumieć ${ }^{26}$. Wskutek takiej aktywności zmniejsza się skłonność do dewaluowania i oskarżania drugiej strony i rośnie poczucie bezpieczeństwa $\mathrm{w}$ relacji z terapeutą, co pozwala na rozwijanie postaw refleksji i rozumienia zamiast walki i obwiniania.

\section{ZACIEKAWIENIE}

Podejście mediolańskie wskazuje na - wydawałoby się oczywistą, ale dotąd wcześniej nie opisywaną $\mathrm{w}$ ten sposób - postawę zaciekawienia jako nadrzędną właściwość terapeuty, sprzyjającą utrzymywaniu opisywanych wcześniej postaw. Postawa ta umożliwia zarówno utrzymanie neutralności, lekceważenie własnych hipotez i kreowanie kolejnych, jak i myślenie w otwarty, cyrkularny sposób, bez zamykania się w prostej ocenie związku przyczynowo-skutkowego. Aktywność terapeuty rodzinnego - opisana przez główne postulaty podejścia mediolańskiego - stanowi propozycję dla mediatora, a w wielu wypadkach opisuje także stosowaną praktykę mediatorów. Podejście mediolańskie opisuje pewną postawę, dzięki której można ominąć opór

25 Por. P. Fonagy, The mentalization-focused approach to social development, $\mathrm{w}$ : The handbook of mentalization-based treatment, eds. J. G. Allen, \& P. Fonagy, John Wiley \& Sons Inc., Chichester 2006, s. 53-99.

26 Por. M. Selvini Palzolli, L. Boscolo, G. Cecchin, G. Prata, Hypothesizing - Circularity - Neutrality..., art. cyt., s. 3-12. 
skonfliktowanych stron. Postawa taka indukuje refleksję obu stron w miejsce odruchowej wrogości i zapewnia udział stron w badaniu problemu. Konsekwentna postawa neutralności, tj. dbania o to, by nie sprzymierzyć się bardziej z którąś ze stron, pozwala skrócić impas wynikający z działań stron na rzecz pozyskania mediatora jako stronnika - każda ze stron czuje, że jest on jej stronnikiem, mimo że nie wypowiada się przeciwko drugiej stronie. Cyrkularne analizy pomagają dostrzec obu stronom własne nastawienie do problemu, wskazując, że związki przyczynowe nie są tak proste, jakby to wskazywała intuicja, i że działanie powoduje reakcję, która zwrotnie wpływa na podmiot działający, eskalując tę reakcję. Na przykład wykładowca, który czuje się nie dość doceniany przez studentów (a w gruncie rzeczy czuje się urażony np. niską frekwencją), stosuje wobec nich represje (np. wymagając na egzaminie zbyt wiele treści na podstawie wykładu), a studenci - zniechęceni podstawą wykładowcy - nie są w stanie zaangażować się w zajęcia albo je opuszczają. W takiej sytuacji można zająć się śledzeniem, po czyjej stronie leży pierwotna przyczyna, ale to prowadzi do eskalacji obronnych postaw. Myślenie cyrkularne każe nam raczej zidentyfikować mechanizm błędnego koła i zająć się nim we współpracy z wykładowcą i studentami. Nie jest to łatwe zadanie, gdyż wymaga takich definicji problemów i sformułowań, które nie byłyby odbierane jako obwinianie którejkolwiek ze stron. Taka praca bardziej przypomina szukanie drogi rozwoju relacji, a nie jej naprawiania. Aktywna postawa mediatora - polegająca na szukaniu takich definicji problemów, które byłyby do przyjęcia dla obu stron - wymaga „hipotezowania”, czyli tworzenia takich hipotez, które niekoniecznie sięgają sedna problemu, gdyż są nie do przyjęcia z powodu obronnych postaw, jednak są dla obu stron użyteczne przy wprowadzaniu zmian. Możliwe, że użyteczna w powyższym przykładzie byłaby hipoteza, że wykładowcy zależy na dobrym wykształceniu studentów w danej dziedzinie, a studentom na tym, żeby wykładowca uwzględniał ich ograniczenia na tym etapie kształcenia. $W$ myśl podejścia mediolańskiego taka hipoteza wymaga przedstawienia i weryfikacji przydatności w rozmowie ze stronami. Jeśli nie okaże się użyteczna, należy stworzyć inną, bardziej użyteczną. Priorytet użyteczności nad prawdziwością nie polega tu na tym, że są to hipotezy fałszywe, ale użyteczne do manipulowania stron, lecz na tym, że mogą być wybiórcze po to, by były konstruktywne. Można sobie wyobrazić, że równie prawdziwa byłaby hipoteza, że studenci lekceważą wykładowcę, a on się mści, tylko wprowadzenie takiej hipotezy 
jest zupełnie nieużyteczne, a nawet przeciw skuteczne. Mediator może nie mieć wpływu na wiele okoliczności, ale z pewnością ma wpływ na swoją postawę zaciekawienia, która stanowi napęd dla pozostałych proponowanych powyżej postaw i aktywności.

\section{Elementy podejścia transgeneracyjnego (przekaz wartości - tradycja, lojalność)}

Podejście transgeneracyjne skupia się na analizie poprzednich pokoleń i ich możliwego wpływu na obecną sytuacji rodziny. Analiza prowadzona jest w oparciu o genogram - szczegółową metodę zapisu relacji w rodzinie, zarówno genealogicznych, jak i powiązanych z nimi relacji, wartości czy trudnych wydarzeń w poprzednich pokoleniach ${ }^{27}$. Z założenia to podejście wydaje się mniej przydatne do rozwiązywania konfliktów w organizacjach - ze względu na konieczność analizowania wątków biograficznych osoby badanej i jej rodziny. Jednak pewnym wyjątkiem może być tu analizowanie systemów wartości stron konfliktu.

Każdy związek dwojga ludzi mierzy się z różnicami wyniesionymi z rodzin, z jakich pochodzą, i koniecznością negocjowania nowej, wspólnej rzeczywistości. Dotyczy to szczególnie konfliktów wartości wyniesionych z rodzin pochodzenia. Chodzi tu nie tylko o różnice w stosunku do systemów ideologicznych, którym podlegają rodziny, z jakich pochodzą, ale także o zupełnie prozaiczne odniesienia do ważności takich wartości jak: wykształcenie, niezależność finansowa, stosunek do obcych, życia towarzyskiego, rozwodów, autonomii, romansów pozamałżeńskich, religijności etc. Część konfliktów wynika ze sprzeczności systemów wartości i imperatywu lojalności wobec wcześniej wyznawanych wartości ${ }^{28}$. W małżeństwach następuje konieczna dla ich sprawnego funkcjonowania adaptacja do różnic systemów wartości wyniesionych z rodzin pochodzenia.

W praktyce mediacyjnej duże znaczenie może mieć badanie, na ile różnice pochodzą z różnych wartości. Łatwo sobie wyobrazić, że w sporze między doktorantem a promotorem działania tego pierwszego będą w znacznym stopniu zdominowane potrzebą bezpieczeństwa, a tego drugiego - potrzebą

27 Por. M. MacGoldrick, R. Gerson, S. Petry, Genograms; Assessment and Treatment (2 ed.), W. W. Norton \& Company, New York-London 2020.

28 Por. I. Boszormenyi-Nagy, G. M. Spark, Invisible Loyalties, Brunner Mazel, London-New York, 1984, s. 37-51. 
rozwoju, co z przyczyn oczywistych może powodować konflikt. Można tu mówić o konflikcie między „pracą dla idei” a „pracą dla pieniędzy” - ten konflikt może być odzwierciedleniem aktualnych potrzeb stron, ale może być także głębiej zakorzeniony, np. w etosie pracy wyniesionym $\mathrm{z}$ rodziny czy poprzednich miejsc pracy. Rozpoznanie źródła wartości może dla mediatora być podstawą rozumienia problemu. Szczególne znaczenie mają lojalności „niewidoczne”. W opisanym powyżej przykładzie konfliktu między studentami a wykładowcą może istnieć niewyrażony konflikt lojalności wobec tradycyjnego modelu edukacji (z dominującą rolą autorytetów) ze strony wykładowcy, a ze strony studentów wobec egalitarnego systemu grupowego, gdzie paternalistyczna troska o studenta ustępuje współudziałowi studentów i nauczycieli w procesie studiowania. Jeśli te przywiązania do ważnych dla siebie wartości i idei pozostają nienazwane i niezidentyfikowane, mogą stanowić trwałą, niewidoczną oś konfliktu. Dopiero odkrycie i nazwanie tych wartości oraz lojalności wobec nich umożliwiają podjęcie działań zmierzających do wypracowania sposobu rozwiązania konfliktu. Oczywiście rozwiązanie musi zakładać respekt i rozumienie odmienności w tym obszarze.

\section{Ograniczenia przenoszenia technik $\mathbf{z}$ terapii rodzin do mediacji}

Mimo zachęcających analogii pracy terapeutycznej i mediacyjnej spotkamy się z wieloma ograniczeniami bezpośredniego transferu technik pracy. Struktura relacji zawodowych różni się znacznie od rodzinnej. W przeciwieństwie do rodziny w organizacjach brakuje trwalej struktury relacji poza organizacją, a uczestnictwo w organizacji ma charakter dobrowolny, często krótkotrwały. W relacje zawodowe ludzie są zaangażowani zwykle kilka godzin dziennie i mają jednocześnie liczne aktywności konkurencyjne. W terapii rodzinnej początkowo dużą trudnością jest zmiana utrwalonej relacji w grupie osób spojonej dość trwałymi więzami, jednak z czasem można zauważyć mocniejsze zaangażowanie grupy w poszukiwaniu sposobu zmiany i większą świadomość, że taki trud jest opłacalną inwestycją.

W pracy mediacyjnej istnieje zasadnicza trudność odnoszenia się do zasobów indywidualnego życia psychicznego w czasie analizy funkcjonowania organizacji czy interwencji na terenie organizacji. Mediator nie ma możliwości interpretowania i badania konfliktu w odniesieniu do indywidualnej 
psychologii, ma także bardzo ograniczone możliwości interpretowania w kontekście rozwoju relacji społecznych (może ograniczyć się jedynie do materiału z przebiegu pracy osoby w organizacji i musi ograniczyć się jedynie do jej terenu). Może to uniemożliwiać - a na pewno bardzo utrudniać - rozwiązywanie tych konfliktów, które są przeniesione z życia prywatnego (np. konflikty na tle mizoginii w stosunku do koleżanek z pracy, gdzie negatywna postawa do kobiet wynika z prywatnych bieżących lub historycznych doświadczeń w relacjach z kobietami).

W mediacji nie ma miejsca na indywidualną terapię psychologiczną, nawet gdyby mediator dysponował wiedzą i umiejętnościami z dziedziny psychologii. Interwencja zupełnie zasadna w psychoterapii (np. „Możliwe, że pana nadodpowiedzialność - $\mathrm{w}$ domyśle tendencja do kontrolowania innych - ma swoje źródło w tym, że jako najstarszy z rodzeństwa, w związku z nieobecnością rodziców, musiał pan się zająć młodszym rodzeństwem”) w konsultacji organizacji czy mediacji przybrałaby inną postać (np. „Czy uważa pan, że intensywność pana działań mogła mieć wpływ na innych?” albo: „Gdyby pan był w sytuacji rodzeństwa, jak pan sądzi, czy opieka pomagałaby panu w rozwoju?"). Sztuką bowiem w mediacji nie jest ocenianie i rozstrzyganie, kto ma rację, ale stosowanie innych technik, np. parafrazowania lub naprowadzania w taki sposób, żeby strona mediacji sama dostrzegła szersze spektrum konfliktu.

W opracowaniu konfliktów w społeczności akademickiej szczególne znaczenie będą miały te podejścia, które skupiają się na pracy w teraźniejszości, gdyż - w przeciwieństwie do terapii rodzin czy par - nie skupiamy się tutaj na zmianach osobowości czy innych właściwości trwałych, nabytych w ciągu życia jednostki, ale na bieżących interakcjach. Abstrahujemy w dużym stopniu od osobistej historii uczestników konfliktu, chociaż pewne aspekty historyczne samego konfliktu mogą mieć znaczenie.

Dużą trudnością we wdrożeniu technik terapeutycznych do praktyki mediacyjnej jest ograniczenie możliwości szkoleniowo-treningowych w tym zakresie dla mediatorów. Środowisko terapeutyczne jest raczej zamknięte na szkolenia osób spoza zawodu. Immanentną cechą szkoleń psychoterapeutycznych jest bazowanie na doświadczeniu klinicznym, ale także własnym, uzyskanym w procesie psychoterapii treningowej, co może być dla szkolonych mediatorów istotnym utrudnieniem. Osoby szkolące psychoterapeutów są również psychoterapeutami i jako tacy mają niewielkie doświadczenie 
w mediacjach. Wypracowanie nowych możliwości szkoleniowych wymagałoby ścisłej współpracy obu środowisk w organizacji szkoleń.

\section{Podsumowanie i wnioski}

Zarówno psychoterapia rodzin i par, jak i mediacje stanowią dziedziny odrębnie się rozwijające, ale także korzystające z dorobku tych samych dziedzin, takich jak: psychologia, socjologia, teorie komunikacji czy techniki lingwistyczne. Zarówno terapia rodzin i par, jak i mediacje mają na celu optymalizację funkcjonowania grup ludzkich - sytemu rodzinnego z jednej strony i innych systemów społecznych z drugiej (choć wiemy, że w przypadku konfliktów między partnerami czy w rodzinie także często stosowana jest mediacja). Mimo tak wielu wspólnych źródeł i celów obie dziedziny nie doczekały się dotąd integracji w jednym modelu teoretycznym. Niniejsza praca jest próbą przybliżenia obu dziedzin na poziomie technik stosowanych w terapii rodzin, a potencjalnie (pewnie często także faktycznie) stosowalnych w mediacjach. Pewne podobieństwa aktywności terapeutów i mediatorów, jak i technik przez nich stosowanych, pozwalają mieć nadzieję, że techniki terapeutyczne mogą być inspiracją dla mediatorów. Jak wskazano w pracy, stosowanie takich technik powinno jednak być wprowadzane ostrożnie, w związku ze sporą liczbą ograniczeń, wynikających z różnic kontekstów społecznych i obszarów oddziaływań obu tych dziedzin. Jakkolwiek kontakty zawodowe - zwłaszcza w obszarze nauki i refleksji - mogą być płodne, to w praktyce do pokonania pozostają jeszcze znaczne bariery między praktykującymi w obu tych dziedzinach.

\section{Bibliografia}

1. Bateson G., Steps to an Ecology of Mind: Collected Essays in Anthropology, Psychiatry, Evolution, and Epistemology. Northvale, Jason Aronson Inc., London 1987.

2. Boszormenyi-Nagy I., Spark, G. M., Invisible Loyalties, Brunner Mazel, LondonNew York, 1984.

3. Bowen M., Intrafamily dynamics in emotional illness, w: Family Therapy in Clinical Practice, ed. M. Bowen, Jason Aronson Inc. New York, 1978, s. 103-117

4. Barbaro de B., Drożdżowicz L., Janusz B., Furgał M., Gdowska K., Czyż P., Kołbik I., Czy terapia rodzin z sadowego ma sens?, „Psychoterapia” (2003) no. 4 (127), s. 35-46. 
5. Dicks H. V., Marital Tensions: Clinical Studies Towards a Psychological Theory of Interaction, Routledge, New York 1993.

6. Fonagy P., The mentalization-focused approach to social development, w: The handbook of mentalization-based treatment, eds. J. G. Allen, \& P. Fonagy, John Wiley \& Sons Inc., Chichester 2006, s. 53-99.

7. Goldenberg H., Goldenberg I., Terapia rodzin, Wydawnictwo Uniwersytetu Jagiellońskiego, Kraków 2006.

8. Harari Y.N., Sapiens. Od zwierząt do bogów, Wydawnictwo Literackie, Warszawa 2018.

9. Heatherington L., Friedlander M. L., Complementarity and symmetry in family therapy communication, „Journal of Counseling Psychology” (1990) no. 37(3), s. 261-268, DOI: https://doi.org/10.1037/0022-0167.37.3.261.

10. Hoffman L., Family therapy: An intimate history, W. W. Norton \& Company 2002.

11. Jabłońska-Dzierża J., Łodej-Sobańska W., Marczewska J., Pawlik J., Podstawowe procesy $i$ zjawiska $w$ terapeutycznej grupie analitycznej, w: Psychoterapia analityczna. Procesy i zjawiska grupowe, red. J. Pawlik, Eneteia, Warszawa 2008, s. 57-107.

12. Kahneman D., Pułapki myślenia, Media Rodzina, Poznań 2012.

13. Luyten P., Fonagy P., The Neurobiology of Mentalizing, „Personality Disorders: Theory, Research, and Treatment” (2015) no. 6 (4), s. 366-379, DOI: http://dx.doi. org/10.1037/peroooo117.

14. MacGoldrick M., Gerson R., Petry S., Genograms; Assessment and Treatment (2 ed.), W.W. Norton \&Company, New York-London 2020.

15. Minuchin S., Families and Family Therapy, Harvard University Press Cambridge, Massachusetts 1974.

16. Namysłowska I., Terapia Rodzin, Wydawnictwo Naukowe PWN, Warszawa 1997.

17. Scharff J. S., Scharff D. E., Object relations Couple Therapy, „American Journal of Psychotherapy" (1997) no. 51 (2), s. 141-173, DOI: http://dx.doi.org/10.1111/famp.12075.

18. Selvini Palzolli M., Boscolo L., Cecchin G. Prata, Hypothesizing - Circularity Neutrality: Three Guidelines for the Conductor of the Session, „Family Process” (1980) no. 19, s. 3-12, DOI:https://doi.org/10.1111/j.1545-5300.1980.00oo3.x

19. Senge P., Iść naprzód; Strategiczne myślenie o budowaniu organizacji uczacych się, w: P.M. Senge, A. Kleiner, C. Roberts, R. B. Ross, \& B.J. Smith, Piąta dysyplina; Materaiaty dla praktyka. Jak budować organizację ucząca się, Wolters Kluwer, Warszawa 2013, s. 31-65.

20. Sikorski C., Język konfliktu. Kultura komunikacji społecznej w organizacji, Wydawnictwo C.H. Beck. Warszawa 2005. 